\title{
Szívinfarktus miatt kezelt betegek prehospitális késési idejének elemzése
}

\author{
Jánosi András dr. ${ }^{1}$ - Csató Gábor dr. ${ }^{2}$ - Pach Ferenc Péter dr. ${ }^{3}$ \\ Pápai György dr. ${ }^{2}$ - Erdős Gergely $d r^{3}$ - Andréka Péter dr. ${ }^{1}$
}

\author{
${ }^{1}$ Gottsegen György Országos Kardiológiai Intézet, Budapest \\ ${ }^{2}$ Országos Mentőszolgálat Budapest \\ ${ }^{3}$ Felsőbbfokú Tanulmányok Intézete, Kőszeg
}

\begin{abstract}
Bevezetés és célkitüzés: A szerzők az ST-elevációval járó szívinfaktus miatt kezelt és invazív ellátásban részesülő betegek prehospitális késését vizsgálták.

Módszer: A Nemzeti Szívinfarktus Regiszter adatbázisában 2014. 01. 01. és 2016. 03. 31. között 7146 olyan beteg volt, akinél percutan coronariaintervenció történt, és az időintervallumok rendelkezésre álltak. A betegek 46\%-ánál (3288 beteg) találtunk mentési adatokat, akiknél a következő időintervallumok vizsgálatára került sor: a panasz kezdetétôl a mentőszolgálat értesítéséig eltelt idő (a beteg késési ideje = BKI), a helyszínre érkezés $(\mathrm{Ml})$, a helyszíni ellátás (M2) és a centrumba érkezés ideje (M3). Amennyiben az első kórházban szívkatéteres laboratórium nem volt, akkor meghatároztuk a Szívkatéteres centrumba érkezésig eltelt időt. A betegeket két csoportba osztottuk: az első felvevőintézet szívkatéteres lehetőséggel rendelkező centrum (C) vagy ilyen feltétellel nem rendelkező kórház (K) volt.

Eredmények: Közvetlenül centrumba került felvételre (primer transzport) 2621 beteg (79,7\%), míg 667 betegnél szekunder transzport történt. A primer transzporttal C-ba került betegek fiatalabbak voltak. A BKI mediánja a C csoportban 114, a K csoportban 121 perc volt. Az M1- és M2-időben lényeges különbség nem volt. Az M3-idő a C csoportban hosszabb volt. A szekunder transzport további 98 perc késéssel járt. A teljes ischaemiás idő lényegesen hosszabb volt a $\mathrm{K}$ csoportban, mint a C csoport betegeinél (356 versus 260 perc).

Következtetés: Az infarktus miatt kezelt betegek hazai ellátása tovább javítható a beteg döntési idejének csökkentésével, valamint a primer transzport arányának növelésével. A mentési idők (M1, M2, M3) megfelelnek az elvárásoknak, de az M2-idő további elemzésével lehetővé válhat a helyszíni ellátás idejének további rövidítése. A centrumokban a felvételtől az ér megnyitásáig eltelt idő optimális.
\end{abstract}

Orv Hetil. 2019; 160(1): 20-25.

Kulcsszavak: ST-elevációval járó szívinfarktus, percutan intervenció, prehospitális késési idő, mentőszolgálat, szívinfarktus-regiszter

\section{Analysis of pre-hospital delay time of patients with myocardial infarction}

Introduction and aim: The authors examined the pre-hospital delay of patients with ST-elevation myocardial infarction receiving percutaneous coronary revascularization.

Method: In the Hungarian Myocardial Infarction Registry (HUMIR), between January 1, 2014 and March 31, 2016, 7146 patients were found who had all necessary time intervals available. In the database of the National Ambulance Service (OMSZ), 3288 patients were found who had the necessary time intervals. The following time intervals were investigated: the time from the beginning of the complaint to the rescue service notification (patient delay time $=$ $\mathrm{PDT})$, the time of the rescue service to arrive at the scene (R1), the on-site care time (R2) and the time from the scene until arriving to the centre (R3). The case of care at the centre, we investigated the time from the onset of symptoms until the balloon inflation (SBI). If the first hospital had no cardiac catheterization laboratory, we measured the transfer time to the cath centre. The methodological details related to the operation of the HUMIR had been described in our earlier communication. Rescue times (R1, R2, R3) were investigated on the basis of the paperbased records of the National Emergency Service. The patients were divided into two groups based on the fact that the first admission hospital is a centre with a heart catheter facility $(\mathrm{C})$ or a non-invasive hospital $(\mathrm{H})$.

Results: 2621 patients (79.7\%) were admitted to a hospital with cath lab (C) and 667 patients with secondary transport. Patients with primary transport to $\mathrm{C}$ were younger, but for other data, the two groups did not differ. The median of PDT for patients in group $\mathrm{C}$ was 114 , and 121 minutes for patients in group $\mathrm{H}$. There was no significant 
difference between $\mathrm{R} 1$ and $\mathrm{R} 2$ time between the two groups. $\mathrm{R} 3$ time in group $\mathrm{C}$ was longer than for $\mathrm{H}$ patients. In the case of secondary transport, the median time was 98 minutes until the centre. The median time from the beginning of the complaint to the balloon inflation (total ischemic time) was 260 minutes in group C and 356 minutes in group $\mathrm{H}$.

Conclusion: Based on the analysis of the total ischemic time and the pre-hospital delay, it is clear that the care of myocardial infarction patients can be further improved by reducing the patient's decision time and increasing the proportion of primary transport. Rescue times (R1, R2, R3) met the expectations, however, further analysis of the M2 time should be considered.

Keywords: ST-elevation myocardial infarction, percutaneous coronary intervention, pre-hospital delay time, ambulance service, myocardial infarction registry

Jánosi A, Csató G, Pach FP, Pápai Gy, Erdős G, Andréka P. [Analysis of pre-hospital delay time of patients with myocardial infarction]. Orv Hetil. 2019; 160(1): 20-25.

(Beérkezett: 2018. július 17.; elfogadva: 2018. augusztus 9.)

\section{Rövidítések}

BKI $=$ a beteg késési ideje (a panasz fellépésétől a mentő értesítéséig eltelt idő); $\mathrm{C}$ = szívkatéteres centrum; $\mathrm{EKG}=$ elektrokardiográfia; $\mathrm{FMC}=$ (first medical contact) az első orvosi ellátás; $\mathrm{K}$ = szívkatéteres lehetôséggel nem rendelkező kórház; Ml = a mentő értesítésétől a helyszínre érkezésig eltelt idő; M2 = a beteg helyszíni ellátásának ideje (a mentőegység helyszínre érkezésétől a kórházba indulásig eltelt idő); M3 = a helyszínrôl indulástól a kórházi felvételig eltelt idő; NSTEMI = ST-eleváció nélküli myocardialis infarctus; NSZR = Nemzeti Szívinfarktus Regiszter; OMSZ = Országos Mentőszolgálat; $\mathrm{PCI}=($ percutaneous coronary intervention $)$ percutan coronariaintervenció; STEMI = ST-elevációval járó myocardialis infarctus; tajszám = társadalombiztosítási azonosító jel; TIT = (total ischemic time) teljes ischemiás idő

Előző tanulmányunkban [1] az ST-elevációval járó szívinfarktusos (STEMI-) betegek ellátását vizsgálva elemeztük a panasz kezdetétől az ér megnyitásáig eltelt idő hosszát, az úgynevezett teljes ischaemiás időt (TIT). Igazoltuk, hogy amennyiben a TIT értéke eléri vagy meghaladja a 400 percet, akkor ez a halálozás szempontjából önálló prognosztikai jelentőséggel bír: a 400 percnél hosszabb TIT esetén a betegek halálozása magasabb. Ugyancsak megállapítottuk, hogy a TIT $80 \%$-a a prehospitális időszakra esik. Jelen vizsgálatunkban a prehospitális idő egyes összetevőit tanulmányoztuk. A prehospitális idő vagy késés több részidőből áll: a beteg elhatározási ideje, a mentő értesítése, a mentő helyszínre érkezése, majd a helyszínről történő elindulás, valamint a beteg megérkezése a szívkatéteres centrumba. A Nemzeti Szívinfarktus Regiszter (NSZR) és az Országos Mentőszolgálat (OMSZ) adatbázisának együttes elemzése lehetővé tette a részidők megismerését és elemzését.

\section{Betegek és módszer}

Az NSZR adatbázisában 2014. január 1. és 2016. március 31. között 10045 olyan beteg szerepelt, akinél ST- elevációval járó infarktus miatt történt kezelés, és a panaszok kezdetétől számított 24 órán belül percutan coronariaintervencióra (PCI) került sor. A teljes ischaemiás idő (a panasz kezdetétől az ér megnyitásáig eltelt idő) vizsgálatához szükséges volt, hogy a releváns adatok (a panasz kezdetének, a kórházba érkezésnek, az invazív laboratóriumba érkezésnek és az ér megnyitásának ideje) hiánytalanul rendelkezésre álljanak. Amennyiben egy betegnek több infarktusa volt, akkor csak az első esemény adatait elemeztük, igy kívántuk biztositani a homogén betegcsoportot. Korábbi vizsgálatunkban - a fenti szempontok figyelembevétele miatt - 7146 beteg ugyanennyi eseményét elemeztük [1]. A jelen tanulmányban a prehospitális késési idő egyes összetevőinek hosszát kívántuk meghatározni azon betegeknél, akik mentővel kerültek kórházba. Az NSZR és az OMSZ adatbázisának együttes feldolgozásával megvizsgáltuk, hogy a 7146 beteghez hány mentőellátás kapcsolódik, illetve hány olyan eseményt találunk, amelynél a szükséges időintervallumok a mentő- és a kórházi dokumentációban hibátlanul szerepelnek és lehetővé teszik az elemzést. Az ellátásokat a tajszám segítségével kapcsoltuk össze. A mentőszolgálatnál ebben az időintervallumban - a belyszini ellátás során - papíralapú dokumentációt használtak, a digitális adatrögzitésre később került sor.

A kórházi ellátás során megkülönböztettük a primer transzportot, amikor a beteg közvetlenül katéteres centrumba került, illetve azokat az eseteket, ahol az első felvevő kórházban invazív kezelésre nem volt lehetőség (1. ábra). Jelen tanulmányunkban összesen 3288 STEMI-beteg esetén elemeztük a prehospitális késés időintervallumait, akik közül 2621 betegnél történt primer transzport. Az adatok feldolgozásához az $\mathrm{R}$ statisztikai programcsomagot használtuk (verzió 3.4.0). A leíró statisztikai jellemzésben a kategóriaváltozók eloszlásait a gyakoriság (illetve az első kategóriára az arányérték) formájában adtuk meg, a folytonos változók esetében átlag (szórás) formájában adtuk meg a jellemzést. A vizsgált betegcsoportok közötti különbségek 


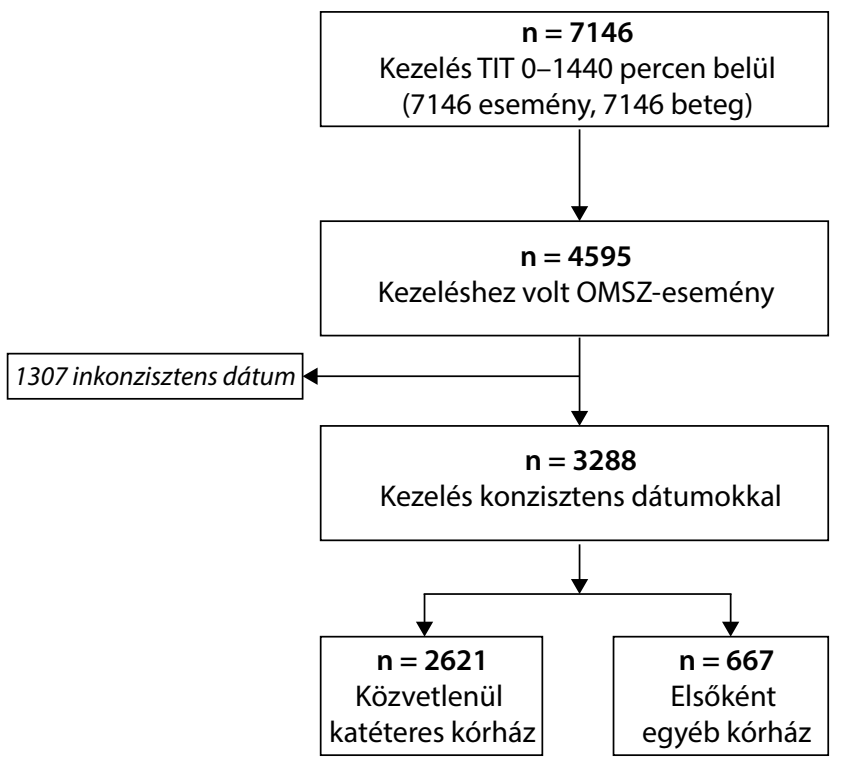

1. ábra $\quad$ A vizsgált betegcsoportok kialakítása

próbastatisztikáihoz a folytonos változóknál Wilcoxonpróbát, a kategóriaváltozóknál pedig khi-négyzet-próbát alkalmaztunk.

\section{Eredmények}

\section{Az elemzésben szereplö betegcsoportok összehasonlitása}

A szívkatéteres centrumba (C), illetve egyéb kórházba (K) került betegek klinikai adatait az l. táblázatban tüntettük fel. A primer transzportban részesült betegek fiatalabbak voltak, de az egyéb klinikai jellemzókben nem találtunk különbséget a két betegcsoport között.

\section{$A$ beteg késési ideje (BKI)}

A C betegcsoportban a panasz kezdetétől a mentő értesítéséig eltelt idő mediánja 114 perc volt, míg a K betegcsoportban 121 perc medián értéket találtunk.

\section{A mentō helyszinre érkezése, a belyszini ellátás és az elsö kórházi felvétel}

Az egyes időszakaszok medián idejét a vizsgált két betegcsoportban a 2. táblázatban tüntettük fel, illetve a 2.ábrán szemléltetjük. A táblázatból látható, hogy a panasz fellépésétől a mentő értesítéséig eltelt idő (BKI) mindkét betegcsoportban igen hosszú, eléri, illetve megközelíti a 2 órát. A két vizsgált betegcsoportban a mentő helyszínre érkezése (M1), a helyszíni ellátás hossza (M2) közel azonos. A helyszínrôl az első felvevő kórházig történő szállítási idő (M3) hosszabb akkor, ha a beteg első felvevőhelye a szívkatéteres centrum. Valószínú, hogy a centrum nagyobb távolságra van a betegtől, mint a helyi kór-
1. táblázat |Az Országos Mentőszolgálat által közvetlenül katéteres kórházba szállított versus az elsőként egyéb kórházba szállított betegek csoportjainak leíró jellemzése

\begin{tabular}{|c|c|c|c|c|}
\hline & & $\begin{array}{l}\text { Közvetlenül } \\
\text { katéteres } \\
\text { kórházba }\end{array}$ & $\begin{array}{l}\text { Egyéb } \\
\text { kórházba }\end{array}$ & $\mathrm{p}$ \\
\hline $\mathrm{n}$ & & 2621 & 667 & \\
\hline \multirow[t]{2}{*}{ (1) Életkor } & Átlag (szórás) & $\begin{array}{l}63,23 \\
(12,5)\end{array}$ & $\begin{array}{c}65,38 \\
(12,85)\end{array}$ & $<0,01$ \\
\hline & $\mathrm{n}$ & 2621 & 667 & \\
\hline \multirow[t]{2}{*}{ (2) Nem } & Férfi & $\begin{array}{l}1667 \\
(63,6 \%)\end{array}$ & $\begin{array}{l}397 \\
(59,5 \%)\end{array}$ & 0,0572 \\
\hline & Nő & 954 & 270 & \\
\hline \multirow[t]{2}{*}{$\begin{array}{l}\text { (9) Szívfrek- } \\
\text { vencia }^{\mathrm{a}}\end{array}$} & Átlag (szórás) & $\begin{array}{r}79,85 \\
(17,70)\end{array}$ & $\begin{array}{c}80,32 \\
(17,53)\end{array}$ & 0,5833 \\
\hline & $\mathrm{n}$ & 2597 & 661 & \\
\hline \multirow[t]{2}{*}{$\begin{array}{l}\text { (10) Szisztolés } \\
\text { vérnyomás }\end{array}$} & Átlag (szórás) & $\begin{array}{c}134,11 \\
(25,39)\end{array}$ & $\begin{array}{l}132,89 \\
(24,85)\end{array}$ & 0,1303 \\
\hline & $\mathrm{n}$ & 2594 & 661 & \\
\hline \multirow{2}{*}{$\begin{array}{l}\text { (11) } \\
\text { Diasztolés } \\
\text { vérnyomás }\end{array}$} & Átlag (szórás) & 80,24 & 79,2 & 0,0560 \\
\hline & $\mathrm{n}$ & $\begin{array}{l}(15,08) \\
2594\end{array}$ & $\begin{array}{l}(14,05) \\
660\end{array}$ & \\
\hline \multirow[t]{4}{*}{$\begin{array}{l}\text { (3) Szívinfark- } \\
\text { tus }^{\text {b }}\end{array}$} & Igen & $\begin{array}{c}383 \\
(14,6 \%)\end{array}$ & $\begin{array}{l}109 \\
(16,3 \%)\end{array}$ & 0,3368 \\
\hline & $\mathrm{Nem}$ & 2142 & 540 & \\
\hline & Nem ismert & 76 & 16 & \\
\hline & Nincs kitöltve & 20 & 2 & \\
\hline \multirow[t]{4}{*}{$\begin{array}{l}\text { (6) Magas } \\
\text { vérnyomás }\end{array}$} & Igen & $\begin{array}{l}1846 \\
(70,4 \%)\end{array}$ & $\begin{array}{l}501 \\
(75,1 \%)\end{array}$ & 0,0419 \\
\hline & Nem & 702 & 154 & \\
\hline & Nem ismert & 53 & 10 & \\
\hline & Nincs kitöltve & 20 & 2 & \\
\hline \multirow{4}{*}{$\begin{array}{l}\text { (8) Periferiális } \\
\text { érbetegség }\end{array}$} & Igen & $218(8,3 \%)$ & $57(8,5 \%)$ & 0,801 \\
\hline & Nem & 2171 & 539 & \\
\hline & Nem ismert & 209 & 67 & \\
\hline & Nincs kitöltve & 23 & 4 & \\
\hline \multirow[t]{4}{*}{ (4) Stroke } & Igen & $152(5,8 \%)$ & $45(6,7 \%)$ & 0,4548 \\
\hline & Nem & 2356 & 602 & \\
\hline & Nem ismert & 89 & 18 & \\
\hline & Nincs kitöltve & 24 & 2 & \\
\hline \multirow[t]{4}{*}{$\begin{array}{l}\text { (7) Diabetes } \\
\text { mellitus }\end{array}$} & Igen & $\begin{array}{c}640 \\
(24,4 \%)\end{array}$ & $\begin{array}{l}179 \\
(26,8 \%)\end{array}$ & 0,3013 \\
\hline & Nem & 1863 & 468 & \\
\hline & Nem ismert & 96 & 18 & \\
\hline & Nincs kitöltve & 22 & 2 & \\
\hline \multirow{4}{*}{$\begin{array}{l}\text { (5) Percutan } \\
\text { coronariain- } \\
\text { tervenciób }^{b}\end{array}$} & Igen & $\begin{array}{c}360 \\
(13,7 \%)\end{array}$ & $\begin{array}{c}91 \\
(13,6 \%)\end{array}$ & 0,9929 \\
\hline & Nem & 2054 & 524 & \\
\hline & Nem ismert & 65 & 10 & \\
\hline & Nincs kitöltve & 142 & 42 & \\
\hline \multirow[t]{2}{*}{ (12) Status } & Él & $\begin{array}{l}2187 \\
(83,4 \%)\end{array}$ & $\begin{array}{l}539 \\
(80,8 \%)\end{array}$ & 0,1201 \\
\hline & Meghalt & 434 & 128 & \\
\hline
\end{tabular}

${ }^{\mathrm{a}}$ Felvételkor

'Kórelőzményben 
2. táblázat |A prehospitális időszak egyes összetevőinek medián ideje percben, valamint a q1 és q3

\begin{tabular}{lcc}
\hline & A beteg centrumba került $(\mathrm{C})$ & $\begin{array}{c}\text { A beteg egyéb kórházba } \\
\text { került }(\mathrm{K})\end{array}$ \\
\hline BKI & $114(49,285)$ & $121(47,289,5)$ \\
M1 & $10(6,17)$ & $11(6,18)$ \\
M2 & $25(17,33)$ & $23(14,5,34)$ \\
M3 & $25(11,40)$ & $16(6,30)$ \\
\hline
\end{tabular}

BKI = a beteg késési ideje (a panasz kezdetétől a mentő értesítéséig eltelt idő); Ml = a mentő értesítésétől a helyszínre érkezésig eltelt idő; M2 = a beteg helyszíni ellátásának ideje (a mentőegység helyszínre érkezésétől a kórházba indulásig eltelt idő); M3 = a helyszínről indulástól a kórházi felvételig eltelt idő

ház. Ha a mentési részidőket együttesen kezeljük (MI + M2 + M3), és ezt a beteg elhatározási idejével (BKI) vetjük össze, akkor megállapítható, hogy a BKI kétszer olyan hosszú, mint a mentési idő.

\section{Az elsö kórházi felvételtöl a centrumban történo" felvételig eltelt ido"}

A vizsgálatunkban szereplő 3288 beteg közül 667 (20\%) olyan kórházba került felvételre, ahol invazív beavatkozásra nem volt lehetőség (K). A 667 betegnél a centrumba jutáshoz másodlagos transzportra volt szükség, ennek medián ideje 98 perc volt.

\section{A centrumba történt felvételtól az ér megnyitásáig eltelt idó}

Az „ajtó-tű idő” igen hasonló volt a két vizsgált betegcsoportban: 40 , illetve 41 perc.

\section{A teljes ischaemiás idô a vizsgált betegcsoportokban}

A közvetlenül katéteres centrumba került betegek (C csoport) esetén a teljes ischaemiás idő mediánja 260 perc volt, míg azon betegeknél, akik szekunder transzporttal kerültek a definitív ellátás helyére (K csoport), ezen idő medián értéke 356 perc volt.

\section{A vizsgált betegcsoportok 30 napos és 1 éves halálozása}

Az elsődlegesen centrumba jutó betegeknél mind a 30 napos $(7,5 \%$ versus $9,5 \%)$, mind az 1 éves ( $16,6 \%$ versus 19,2\%) halálozás kedvezőbb volt.

\section{Megbeszélés}

Az ST-elevációval járó szívinfarktus miatt kezelt betegek esetén a revascularisatio idejének döntő - az életkilátásokat is befolyásoló - jelentősége van. Optimális esetben a diagnózis felállításától számított 120 percen belül az ér percutan intervencióval történő megnyitására sor kerül, illetve ha ez nem lehetséges, akkor a gyógyszeres revascularisatio megelőzi a katéterterápiás beavatkozást [2]. Előző vizsgálatunkban - több év adatait feldolgozva azt találtuk, hogy Magyarországon a panasz kezdetétől az ér megnyitásáig eltelt idő (teljes ischaemiás idő) mediánja meghaladja a 3 órát, és ennek döntő része, $80 \%$-a prehospitális késés [1]. Figyelembe véve azt, hogy a gyógyszeres érmegnyitás hazánkban alig kerül alkalmazásra (a gyakoriság évek óta 0,5\% alatt van), a hosszú prehospitális késés következtében a primer PCI során a megmentett szívizom tömege biztosan elmarad attól, ami az optimális időben végzett kezelés során várható

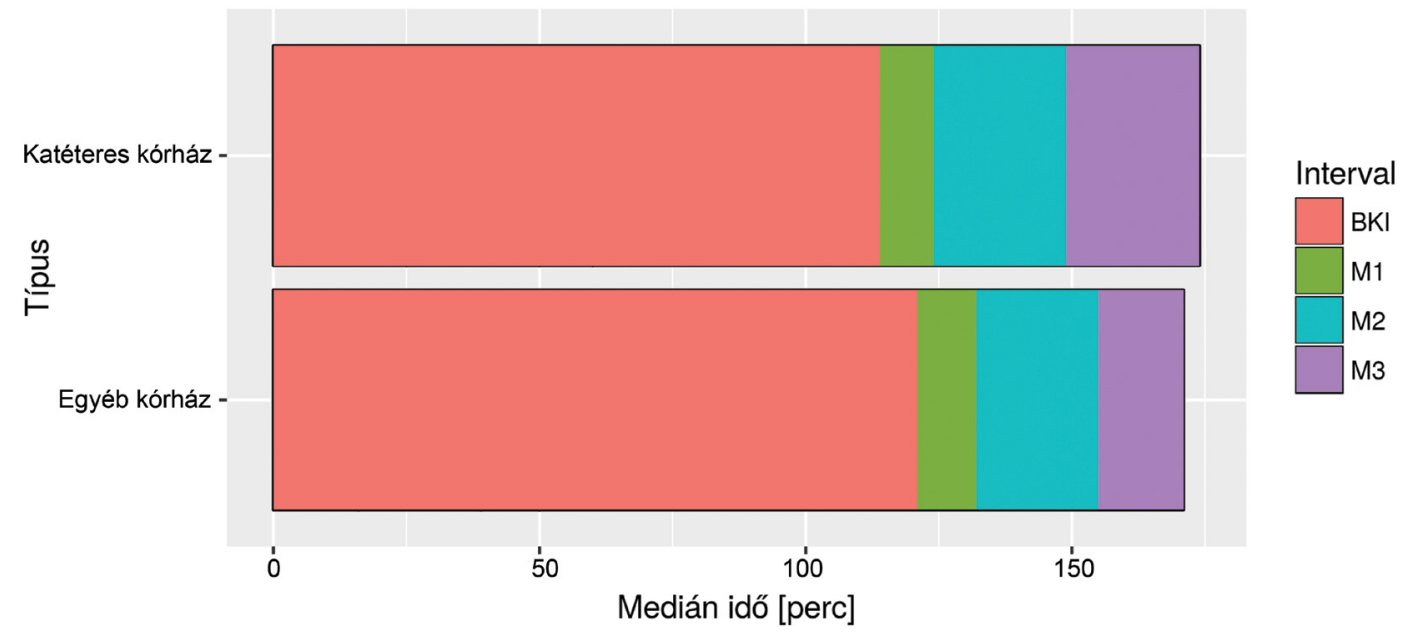

\begin{tabular}{l|l} 
2. ábra & $\begin{array}{l}\text { A prehospitális kezelési idő összetevői a két betegcsoport esetén } \\
\text { BKI }=\text { a beteg késési ideje: a panasz fellépésétől a mentő értesítéséig eltelt idő; M1 = a mentő értesítésétool a helyszínre érkezésig eltelt idő; M2 = a } \\
\text { beteg helyszíni ellátásának ideje (a mentóegység helyszínre érkezésétől a kórházba indulásig eltelt idő); M3 = a szállítási idő (a helyszínről a kórházba } \\
\text { érkezésig eltelt idő) }\end{array}$
\end{tabular} 
lenne. Tekintettel arra, hogy a prehospitális idő szakaszaira vonatkozóan eddig nem rendelkeztünk hazai adatokkal, jelen vizsgálatunkban ezen idő elemzését tűztük ki célul. A Nemzeti Szívinfarktus Regiszter és az Országos Mentőszolgálat adatainak együttes elemzésével a beteg késése (BKI, „patient delay”) és a rendszer késése („system delay") megállapítható, és ezt követően lehetővé válhat a már említett kedvezőtlen helyzet javítása. Vizsgálatunkban a panasz jelentkezésétől számítva 2 óra telik el addig, amíg a beteg elhatározza, hogy segítséget kér. Lényegében már ekkor eldől, hogy a beavatkozásra csak az optimális eredményt biztosító időablakon túl kerülhet sor. Adataink szerint a mentő értesítését követő 20-30 perc múlva kerülhetett sor a diagnózis felállítására $(\mathrm{Ml}+$ M2). Adataink szerint a panasz kezdetétől a diagnózis felállításáig eltelt idő mediánja 144-151 perc. Finn szerzők hasonlóan hosszú BKI-ről számolnak be [3]. Widimsky és mtsai [4] több európai ország adatait összefoglaló tanulmányában a beteg késési ideje 60 és 210 perc között volt. Franciaországban a FAST-MI 2005. évi adatai szerint a beteg elhatározási idejének mediánja - a revascularisatio módjától függóen - 60, illetve 75 perc volt [5], míg egy 2015-ben végzett felméréskor a BKI mediánja 90 perc volt [6]. A bécsi STEMI-regiszterben végzett felmérés szerint a BKI 91 perc volt [7]. Ängerud és mtsai [8] közlése szerint Svédországban STEMI esetén 70 perc, az NSTEMI-betegcsoportban 125 perc volt a 'first medical contact'-ig (FMC) eltelt idő. Különböző típusú infarktusokat vizsgálva STEMI esetén a betegek lényegesen rövidebb idő alatt kértek segítséget, mint NSTEMI esetén. Az ACTION Regiszter az Accelerator-2 vizsgálat kapcsán a 12 amerikai metropoliszrégió szervezett STEMI-ellátásának eredményességével kapcsolatban igen biztató eredményeket közöltek [9]. A betegek késési idejének mediánja 50 perc volt, és a program végső szakaszában a betegek háromnegyedénél, a FMCtôl számított 90 percen belül az érmegnyitásra sor került. A kezelésig eltelt idő csökkenésének jelentőségét a halálozási adatok javulása igazolta. Az irodalmi adatok többsége azt igazolja, hogy a BKI a legtöbb országban rövidebb, mint Magyarországon, és arra is van bizonyíték, hogy szervezési intézkedésekkel ez az idő optimális értékre csökkenthető [9]. Több tanulmányban vizsgálták a betegek késésének okát. Svéd szerzők nők esetén 30 perccel hosszabbnak találták a döntési időt [10]. Jäger és mtsai [7] adatai szerint a FMC-ig eltelt idő nóknél, anterior infarctus és diabetes társbetegség fennállásakor hosszabb, kardiogén sokk esetén rövidebb idő alatt került sor az FMC-re. Koreai adatok szerint [11] magasabb iskolai végzettség esetén a prehospitális idő rövidebb volt. A mentő értesítése és a helyszínre érkezés közötti idő mediánját vizsgálatunkban 10 percnek találtuk, a teljes mentési idő - a szolgálat értesítésétől a kórházi felvételig - pedig 60 perc volt. Ez az idő rövidebb, mint amit Pfister és mtsai közöltek [12], megfelel az aján- lásokban szereplő elvárásnak. Az M2-idő részletesebb elemzése, a helyszíni teendók pontosítása azonban 1020\%-os további időmegtakarítást eredményezhet. Alapvető kérdés, hogy a prehospitális késés milyen úton csökkenthető. Tekintettel arra, hogy a prehospitális késéssel kapcsolatban a legfontosabb probléma a beteg döntési idejének hossza, több tanulmányban a betegedukáció hatásosságát vizsgálták, esetenként közvetlen intervenció, máskor a tömegmédia felhasználásával. Egy amerikai multicentrikus tanulmányban [13] a médián keresztüli oktatás eredményességét nem sikerült igazolni, ezzel szemben több vizsgálatban kedvező tapasztalatokat szereztek különböző edukációs formák alkalmazásával [14, 15]. Néhány tanulmányban telemedicinális módszerekkel (például transztelefonikus EKG alkalmazásával) igyekeztek csökkenteni a prehospitális késést $[10,16]$. Vizsgálatunkban nagyszámú beteg adatainak elemzésével hazánkban elsőként elemeztük a prehospitális idő összetevőit, rámutattunk arra, hogy a prehospitális késés legfontosabb eleme a beteg késlekedése. A kezelés eredményessége szempontjából alapvető jelentőségű a minél korábbi intervenció, ennek eléréséhez a beteg okozta késési idő csökkentésén keresztül vezet az út. A betegedukáció hatékonyságára nincs nagy esetszámú, egyértelmú bizonyíték, de ezt a tevékenységet ennek ellenére sem hagyhatjuk ki abból a törekvésből, amelynek célja a késési idő csökkentése. Vizsgálatunk korlátját jelenti, hogy a betegek több mint felénél - a dokumentáció hiányos vagy pontatlan volta miatt - nem sikerült a prehospitális idő részleteinek megismerése. A mentési adatok belyszini digitális rögzítése ezen a téren is elörelépést jelenthet. További kutatási feladatot jelent annak vizsgálata, hogy mi az oka annak, hogy a betegek ötöde egyáltalán nem került invazín centrumba, illetve miért hosszú a szekunder transzport ideje. Ezen kérdések megválaszolása-a klinikai szituációk sokfélesége miatt - esettanulmányok segitségével lehetséges.

Anyagi támogatás: A szerzők anyagi támogatásban nem részesültek.

Szerzôi munkamegosztás: J. A.: A kutatási terv kidolgozása, adatgyújtés, a kézirat megírása. Cs. G.: A mentőszolgálat adatainak összegyưjtése, a kézirat elkészítésében való részvétel. P. F. P.: A statisztikai elemzések elkészítése, a kézirat végleges formájának kialakításában való részvétel. P. Gy.: A mentőszolgálat adatainak összegyưjitése, az irodalom feldolgozása. E. G.: A kiemelt halálozási kockázattal járó betegségek kutatásának projektvezetője. A. P.: A statisztikai elemzés értékelése, a kézirat végleges formájának kialakításában való részvétel. A cikk végleges változatát valamennyi szerző elolvasta és jóváhagyta.

Érdekeltségek: A szerzőknek nincsenek érdekeltségeik. 


\section{Irodalom}

[1] Jánosi A, Erdős G, Pach FP, et al. Prognostic significance of the total ischemic time in patients with ST-elevation myocardial infarction. [A teljes ischaemiás idő prognosztikus jelentősége az ST-elevációval járó szívinfarktus miatt kezelt betegekben.] Orv Hetil. 2018; 159: 1113-1120. [Hungarian]

[2] Ibanez B, James S, Agewall S, et al. 2017 ESC Guidelines for the management of acute myocardial infarction in patients presenting with ST-segment elevation: The Task Force for the management of acute myocardial infarction in patients presenting with ST-segment elevation of the European Society of Cardiology (ESC). Eur Heart J. 2018; 39: 119-177.

[3] Helve S, Viikilä J, Laine M, et al. Trends in treatment delays for patients with acute ST-elevation myocardial infarction treated with primary percutaneous coronary intervention. BMC Cardiovasc Disord. 2014; 14: 115

[4] Widimsky P, Wijns W, Fajedet J, et al. Reperfusion therapy for ST elevation acute myocardial infarction in Europe: description of the current situation in 30 countries. Eur Heart J. 2010; 31: 943-957.

[5] Danchin N, Puymirat E, Steg PG, et al. Five-year survival in patients with ST-segment-elevation myocardial infarction according to modalities of reperfusion therapy: the French Registry on Acute ST-Elevation and Non-ST-Elevation Myocardial Infarction (FAST-MI) 2005 Cohort. Circulation 2014; 129: 16291636

[6] Belle L, Cayla G, Cottin Y, et al. French Registry on Acute STelevation and Non-ST-elevation Myocardial Infarction 2015 (FAST-MI 2015). Design and baseline data. Arch Cardiovasc Dis. 2017; 110: 366-378.

[7] Jäger B, Farhan S, Rohla M, et al. Clinical predictors of patient related delay in the VIENNA ST-elevation myocardial infarction network and impact on long-term mortality. Eur Heart J Acute Cardiovasc Care 2017; 6: 254-261.

[8] Ängerud KH, Sederholm Lawesson S, Isaksson RM, at al. Differences in symptoms, first medical contact and pre-hospital delay times between patients with ST- and non-ST-elevation myocar- dial infarction. Eur Heart J Acute Cardiovasc Care 2017; Nov 1. doi: $10.1177 / 2048872617741734$ [Epub ahead of print]

[9] Jollis JG, Al-Khalidi HR, Roettig ML, et al. Impact of regionalization of ST-segment-elevation myocardial infarction care on treatment times and outcomes for emergency medical servicestransported patients presenting to hospitals with percutaneous coronary intervention: Mission: Lifeline Accelerator-2. Circulation 2018; 137: 376-387.

[10] Rasmussen MB, Frost L, Stengaard C, et al. Diagnostic performance and system delay using telemedicine for pre-hospital diagnosis in triaging and treatment of STEMI. Heart 2014; 100: 711-715.

[11] Heo JY, Hong KJ, Shin SD, et al. Association of educational level with delay of pre-hospital care before reperfusion in STEMI. Am J Emerg Med. 2015; 33: 1760-1769.

[12] Pfister R, Lee S, Kuhr K, et al. Impact of the type of first medical contact within a guideline-conform ST-elevation myocardial infarction network: a prospective observational registry study. PLOS ONE 2016; 11: e0156769.

[13] Dracup K, McKinley S, Riegel B, et al. A randomized clinical trial to reduce patient pre-hospital delay to treatment in acute coronary syndrome. Circ Cardiovasc Qual Outcomes 2009; 2: $524-532$.

[14] Mooney M, McKee G, Fealy G, et al. A randomized controlled trial to reduce pre-hospital delay time in patients with acute coronary syndrome (ACS). J Emerg Med. 2014; 46: 495-506.

[15] Bray JE, Stub D, Ngu P, et al. Mass media campaigns' influence on prehospital behavior for acute coronary syndromes: an evaluation of the Australian Heart Foundation's warning signs campaign. J Am Heart Assoc. 2015; 4: e001927.

[16] Papai G, Racz I, Czuriga D, et al. Transtelephonic electrocardiography in the management of patients with acute coronary syndrome. J Electrocardiol. 2014; 47: 294-299.

(Jánosi András dr., Budapest, Haller u 29., 1096 e-mail: andras.janosi@kardio.hu)

\title{
Felhívás előfizetésre
}

\author{
Legyen Olvasónk a következő évben is! \\ Fizessen elő az Orvosi Hetilap 2019-es évfolyamára! \\ Egy füzet ára: $1150 \mathrm{Ft}$. \\ Éves előfizetési dij: $49900 \mathrm{Ft}$, nyugdíjasoknak: $39990 \mathrm{Ft}$. \\ Az online változat éves előfizetési dijja: $29990 \mathrm{Ft}$.
}

